Dieses Dokument ist eine Zweitveröffentlichung (Postprint) /

This is a self-archiving document (postprint):

Michael Dobler

Rethinking revenue recognition - the case of construction contracts under International Financial Reporting Standards

Erstveröffentlichung in / First published in:

International Journal of Revenue Management (IJRM). 2008, 2(1), S. 1-22. Inderscience Online Journals. ISSN 1741-8186.

DOI: https://doi.org/10.1504/I]RM.2008.018175

Diese Version ist verfügbar / This version is available on:

https://nbn-resolving.org/urn:nbn:de:bsz:14-qucosa2-364528 


\title{
Rethinking revenue recognition - the case of construction contracts under International Financial Reporting Standards
}

\author{
Michael Dobler*
}

\begin{abstract}
Revenue recognition is one of the most crucial issues in financial reporting and the prevalent source for recent accounting scandals. International financial reporting standard setters are conducting a major project rethinking revenue recognition. Tentative proposals of the project Revenue Recognition feature an asset-liability approach relying on measurement at fair values or at allocated customer consideration amounts. This paper chooses construction contracts to illustrate and to evaluate the farreaching changes implied by the proposals in a multi-period context. Main results suggest that the proposals are ambivalent in terms of relevance but critical in terms of reliability compared to the recent treatment under IAS 11. Particularly, a pure fair value approach yields irritating patterns of revenue recognition found inappropriate for stewardship purposes. While its adoption for revenue recognition under IFRSs is unlikely due to regulatory incompatibilities, measuring performance obligations at allocated consideration amount partly mitigates the concerns.
\end{abstract}

This is the accepted version of the manuscript, manuscript, accepted for publication, i.e. post-review, pre-typesetting.

Paper accepted and published by Inderscience Publishers in the International Journal of Revenue Management (IJRM):

Dobler, Michael (2008). Rethinking revenue recognition - the case of construction contracts under International Financial Reporting Standards. International Journal of Revenue Management, Vol. 2 No. 1, pp. 1-22. https://doi.org/10.1504/IJRM.2008.018175

International Journal of Revenue Management:

https://www.inderscience.com/ijrm

Inderscience Publishers:

https://www.inderscience.com

Dr. Michael Dobler, MBR, Chair on Accounting and Auditing, Munich School of Management, Ludwig-Maximilians-University Munich, Ludwigstr. 28/RG IV, D-80539 Munich, Germany.Email: dobler@bwl.lmu.de. 


\section{Introduction}

International Financial Reporting Standards (IFRSs) are heading to become a globally accepted financial reporting system. Since 2005 IFRSs have been compulsory for (at least) group accounts of listed companies in the European Union. Approximately 100 countries worldwide have either adopted IFRSs or linked their national accounting systems closely to IFRSs. While relying on "profit ... as a measure of performance" (Framework.69), IFRSs do lack a well-founded concept of profit. Particularly, regulations on revenue recognition show inconsistencies and loopholes (Haller and Schloßgangl, 2005; Wüstemann and Kierzek, 2005). Under United States Generally Accepted Accounting Principles (US GAAP), revenue recognition is addressed by almost 200 references which are not fully consistent either. Yet, revenue recognition is one of the most crucial issues in financial reporting internationally and was the prevalent source for recent accounting scandals (Government Accountability Office, 2002, 2006; Benston et al., 2003).

Given (1) deficiencies in both IFRSs and US GAAP and (2) the aim of convergence, the International Accounting Standards Board (IASB) and the Financial Accounting Standards Board (FASB) have been rethinking revenue recognition in a joint project since 2002. Largely independent from current financial reporting standards, the project Revenue Recognition aims at a general principles-based standard featuring a conceptually sound revenue recognition model. This standard shall replace current standards on revenue recognition, particularly International Accounting Standard (IAS) 11 and IAS 18. The tentative proposals feature a valuation-based asset-liability approach with the measurement at fair values or at allocated customer consideration amounts (IASB, 2005c; IASB and FASB, 2007). While all decisions made to date are 
tentative, the project debate and proposals spark new interest in concepts of income and imply far reaching changes in revenue recognition compared to recent IFRSs. As construction contracts, currently addressed by IAS 11, are multi-period projects, they give rise to particular problems of revenue and expense recognition. Thus, construction contracts provide a unique example to illustrate and discuss implications and consequences of the proposed approaches, which are invisible in a single-period context.

This paper is among the very first to investigate the project Revenue Recognition (Ernstberger, 2005; Wüstemann and Kierzek, 2005, 2006), even before the standardsetters have published their discussion paper on the approaches developed since 2002. Its main distinguishing features and objectives are first to illustrate and compare the recent and proposed approaches for revenue recognition under IFRSs with particular regard to construction contracts. This shall be accomplished by illustrating the main regulations in seven versions of a numerical example highlighting their differences. The second objective is to evaluate these differences and the proposals of the project Revenue Recognition from a financial reporting perspective. This requires a discussion with respect to (1) income concepts, (2) characteristics and (3) objectives of financial reporting and (4) regulatory compatibility.

Main results show that the proposed approaches are ambivalent in terms of relevance and more critical in terms of reliability of financial reporting for construction contracts compared to IAS 11. Particularly, the fair value approach (FVA) yields irritating patterns of revenue recognition and appears to conflict with the reliability and stewardship function of financial reporting, partially mitigated under the allocated customer consideration approach (ACCA) proposed. Due to ambiguity of concepts, this 
implies inconsistencies with both the current framework of IASB and endorsement criteria set out by the European Union (Regulation (EC) 1606/2002, Art. 3(2)). While revising the framework as currently proposed (IASB, 2006f) can ease the former inconsistencies, the latter tend to remain and are likely to impede the adoption of the FVA for construction contracts under IFRSs.

The financial reporting perspective on revenue recognition, as advocated in this paper, acknowledges that revenue management "focuses on revenue growth, not on costcutting and downsizing. It drives the bottom line, and improves the topline" (Chase, 1999, p.2). It also clarifies the issue since revenue is the top line and profit (net-revenue) is the bottom line of financial income statements. These are quantitative measures for the performance of the business including revenue management practices. While the revenue management literature discusses various and more sophisticated approaches for performance evaluation, revenue and profit as displayed in financial statements play an important role (e.g. Harris, 2007; Chiang, Chen and Xi, 2007). They are the key figures for investors in general (for survey Kothari, 2001) and for those considering construction contracts in particular (Trotman and Zimmer, 1986; Barlev, 1995). Since financial reporting and managerial accounting are converging (to some extent), the concepts discussed are not limited to financial reporting. They can provide impetus to rethink revenue recognition in the construction industry for internal performance measurement as well.

The remainder of the paper is organised as follows. The next section provides conceptual background. Sections 3 and 4 illustrate the recent and the proposed approaches, respectively. Section 5 discusses and evaluates the approaches, followed by conclusions. 


\section{Conceptual background}

\subsection{Objectives and characteristics of financial reporting}

Internationally, as aimed at specifically in the current conceptual framework by IASB, there are two major objectives of financial reporting. Financial reports shall "provide information about the financial position, performance and changes in financial position of an enterprise that is useful ... in making economic decisions" (Framework 12). Moreover, reports shall "show the results of the stewardship of management, or the accountability of management for the resources entrusted to it" (Framework 14). While stating both objectives, IFRSs are more focused on decision-usefulness which is explicitly assumed to comprise the stewardship function in the current debate on revising the conceptual frameworks of the IASB and of the FASB (IASB, 2006f).

While usefulness of information is ambiguous without a semiotic and double-semiotic perspective (Will, 2006), the IASB assumes that 'qualitative characteristics' of financial information constitute their decision-usefulness; however, the main characteristics of relevance and reliability are still not clearly defined and ambiguous (Fetzer and Almeder, 1993; Will, 2006). According to Framework 26 "[i]nformation has the quality of relevance when it influences the economic decisions of users by helping them evaluate past, present or future events or confirming, or correcting their past evaluations". This definition appears tautological given that there is no alternative in changing a decision or not. In contrast, economics of information imply that relevance in a decision-making context requires a change in decisions (e.g. Demski, 1980; 
Ballwieser, 2004); philosophy science refers to evidential relevance, where a sentence is relevant to a hypothesis only if the truth or falsity of the former makes a difference to the truth or falsity of the latter (e.g. Fetzer and Almeder, 1993).[1] Given that financial reporting is for many and inhomogeneous users, the IASB (2006f) rather aims at information it assumes capable to affect decisions of a wide range of users, particularly investors (and creditors). Framework 31 assumes reliability of information as faithfully representing what it purports to represent. The information shall be free from error or bias by management and verifiable. Given recent proposals for a revised framework reliability is likely to be replaced by faithful representation (IASB, 2006f), which refers to semantic correspondence with reality (as a type of truth), it can be seen as the "property of a method, mechanism, or process by virtue of which it tends to produce true beliefs rather than false beliefs" (Fetzer and Almeder, 1993, p.122). Still, reliability can conflict with relevance. For instance, historical costs are reliable measures (Kosiol, 1978), but they might not be relevant for decision-making (Ijiri, 1975). Any rational decision-maker will ignore a message assumed not to be reliable since it cannot be decision-useful (Crawford and Sobel, 1982).

The stewardship function of financial reporting implies that investors have the right to get information about the use of their invested capital. This is an integral part of accountability in the relationship between agents and principals aiming at investors' rational confidence in the managers' respects of their rights (Berle and Means, 1932; Will, 2006). While the objectives of stewardship and decision-usefulness overlap, accounting standards do influence the decisions of managers (Birnberg, 1980; Hunt, 1995). Thus, accounting standards need to be evaluated upon the incentives induced on managers. Given that the stewardship function requires reliable reports while decisionusefulness allows for balancing relevance and reliability, both objectives cannot 
simultaneously be achieved by using the same set of standards in general (Gjesdal, 1981; Antle and Demski, 1989; Christensen and Demski, 2003).

\subsection{Income concepts}

An economic benchmark for profit is the concept of economic income. It defines income as the increase in wealth (Smith, 1870). Fisher (1906) shows that under certain conditions, income equals the interest on wealth at the beginning of the period if wealth is derived by discounting future cash flows (Solomons, 1961). Economic income is forward-looking, relevant for decision-making purposes and appropriate to show stewardship (Christensen and Demski, 2003). However, when relaxing the conditions of perfect and complete markets, i.e. when leaving a stylised world in which income reporting is dispensable, economic income measurement becomes subjective (Beaver and Demski, 1979). Since the necessary assumptions about the future are subject to managerial discretion, the income figure becomes likely to lack reliability.

Accounting theory distinguishes two major (partly overlapping and again ambiguous) concepts of profit. Under the revenue-expense approach, accounting profit is the difference between realised income and expense following from transactions and events in the corresponding period. The approach focuses on the recognition criteria for income and expenses to compute profit. While assets and liabilities are generally carried at historical cost until they are used up or sold, revenues and expenses are matched (Paton and Littleton, 1955; Ijiri, 1975; Belkaoui, 2000). This is assumed to yield a rather reliable measure for profit which is, however, of relevance for few decisions to be taken (Chambers, 1966; for a discussion Leuz, 1998). Particularly under conservative 
accounting, future losses are anticipated while future profits are not (Devine, 1963). The asymmetric treatment yields a systematically biased profit figure.

In contrast, the asset-liability approach defines profit as changes in values of assets and liabilities. Thus, profit consists of both, realised and unrealised components. Values discussed include current values, market values and historical cost (Edwards and Bell, 1961; Benston et al., 2006). Current or market values are not well defined because they can either be entry or exit values. If the market prices are not observable, the values have to be estimated giving rise to managerial discretion and problems of reliability (Bromwich, 2004; Hitz, 2007).

Noteworthy, the revenue-expense approach may be understood as an asset-liability approach carrying assets and liabilities at historical cost yielding 'pagatoric' (Kosiol, 1978) profit. For sake of clarity, the proceeding sections refer to the asset-liability approach for any other measurement base.

\section{Construction contracts under IAS 11}

\subsection{Definitions and concepts}

IAS 11.3 defines a construction contract as "a contract specifically negotiated for the construction of an asset or a combination of assets that are closely interrelated or interdependent". Contracts are combined and segmented according to substance over form as specified in IAS 11.7-10. 
The accounting treatment of both contract revenue and contract costs depends on whether the economic outcome of the contract can be estimated reliably (Barlev, 1995). IAS 11.23-24 determine this condition by requiring two or four criteria to be satisfied for cost plus or fixed price contracts, respectively. For the latter, the criteria are stricter because the contractor bears higher risk compared to cost plus contracts. Entities have to account for revenues and expenses attributable to construction contracts following

(1) the zero profit margin method (ZPMM), when the outcome cannot be estimated reliably;

(2) the stage of completion method (SOCM), otherwise.

Under both approaches, an expected loss on the construction contract has to be immediately recognised as an expense (IAS 11.36).

\subsection{Zero profit margin method (ZPMM)}

Under the ZPMM, contract costs are recognized as an expense in the period of incurrence. Revenues are recognized to the extent of recoverable contract costs incurred (IAS 11.32). Profit is shown when the contract is completed.

[PLEASE INSERT EXAPLE A.] 


\subsection{Stage of completion method (SOCM)}

In contrast, under the SOCM (or percentage of completion method), "contract revenue and contract costs ... should be recognised as revenue and expense respectively by reference to the stage of completion of the contract activity at the balance sheet date." (IAS 11.22) The stage of completion can be determined from

(1) an input perspective, e.g., cost-to-cost method or labour hours method;

(2) an output perspective, e.g., physical observation method.

In practice, the cost-to-cost method is most common. As a matter of fact, this method yields expenses equalling the contract costs incurred in each period. Other methods generally do not. Then, contract costs have to be adjusted.[2] Any changes in estimates are accounted for according to IAS 8.

\section{[PLEASE INSERT EXAPLE B.]}

4 Construction contracts under the proposals of the project Revenue Recognition

\subsection{Definitions and concepts}

The project Revenue Recognition follows an asset-liability approach instead of a revenue-expense approach (FASB, 2002; IASB, 2002). The boards assume that a revenue-expense approach yields severe problems with defining earnings processes and is too difficult to be followed. Rather they aim at recognising revenue on the basis of 
changes in assets and liabilities arising from contracts with customers without considering supplemental realisation or earnings criteria (Ernstberger, 2005; Wüstemann and Kierzek, 2005; IASB and FASB, 2007).

According to the proposed model, enforceable contracts with customers can give rise to assets and liabilities. A contract is a set of explicit or implicit promises which a court will enforce. Large penalties for a breach of a contract and pre-payment can indicate enforceability. Contract inception shall be determined according to general customary business practice and the entity's specific conduct. While contractual rights need not be worthy of enforcement, i.e. costs of enforcement exceed its benefits for the potential plaintiff, rights or obligations shall be unconditional or mature to give rise to assets or liabilities (IASB, 2004c; IASB and FASB, 2007). Unconditional contractual rights and obligations can be characterised by only requiring the passage to make performance due. They are non-contingent items as opposed to conditional ones subject to the occurrence or non-occurrence of one or more uncertain events.

To illustrate the difference in a contractual setting, suggest a product warranty. While the obligation of the entity issuing a warranty is conditional, there is the unconditional obligation to stand-ready to provide warranty coverage. Only the latter gives rise to a liability (Wüstemann and Kierzek, 2005; IASB and FASB, 2007). These concepts are also discussed in further projects, including Conceptual Framework and Liabilities (FASB, 2005; IASB, 2005g, 2007a). What emerges in all these projects is that the probability of future inflows or outflows of resources embodying economic benefits shall no longer be included in the definitions of elements but shall affect their measurement. 
IASB agreed on the rebuttable presumption that the unit of account is a whole contract if the subjects of a wholly or partially executory contract are fungible and the legal remedy for a breach is money. But if the subjects are unique and legal remedy is specific performance, the unit of account shall be the assets and liabilities arising.[3] Performance obligations are tentatively defined as legally enforceable obligation of a reporting entity to its customer, under which the entity is obligated to provide goods, services, or other rights. Performance obligations shall be separated from the customer's perspective, i.e. based on whether the performance has identifiable utility to the customer. Utility to the customer shall be assumed if the goods, services, or other rights underlying the performance obligation can either be resold separately by the customer (in a market still to be specified) or be sold separately or as an optional extra by another vendor. Moreover, unconditional stand-ready obligations are assumed to have utility to the customer and shall be a separate unit of account (IASB, 2006b; IASB and FASB, 2007).

There are two perspectives discussed to define revenue more precisely, which mainly differ when third parties perform (IASB, 2004a, 2006a, 2006d):

(1) Revenues are increases in the reporting entity's assets or decreases in its liabilities resulting from activities which are integral to the provision of goods, services, or other rights ultimately destined for customers by the entity itself (broad performance view).

(2) Revenues are decreases in the reporting entity's liabilities resulting from the extinguishment of performance obligations irrespective of whether the entity itself or third parties perform on behalf of the entity (liability extinguishment view). 
The latter view seems to be preferred given that IASB tentatively decided that “performance by third parties of the entity's obligations ... unless those third parties legally assume those obligations." (IASB, 2004b). Recently, the notion of customer acceptance is further explored (IASB, 2006b, 2006d). The IASB acknowledges that income shall be defined before revenue can be defined and that the distinction between revenues and gains shall be sharpened (IASB, 2004c). To date, no decision is reached on that distinction.

While assets arising from contractual rights shall be measured at their fair value considering credit risk and the value of money if material (IASB, 2004b), there is controversy on the measurement of performance obligations. Until mid-2005, the project relied on the fair value. Due to diverging notions and problems of the measurement approach, the IASB and the FASB now explore an alternative measurement basis, which allocates the total consideration among the performance obligations based on estimated sales prices in general. Thus, two - potentially mixed measurement approaches for performance obligations are discussed (IASB 2006e, 2007b):

(1) fair value approach (FVA); and

(2) allocated customer consideration approach (ACCA).

\subsection{Fair value approach (FVA)}

The fair value is defined as "the amount for which an asset could be exchanged, or a liability settled, between knowledgeable, willing parties in an arm's length transaction" 
(e.g. IAS 18.7). The project refers to the fair value particularly as a legal layoff amount, i.e. the amount which the reporting entity would have to pay to transfer the performance obligation to another entity in a business-to-business market (IASB, 2005a). While the boards discussed a variety of approaches to measure this kind of exit fair value, including transactions of competitors and proposed transactions, they basically agreed the FASB's fair value hierarchy, currently under discussion (Hague et al., 2006; IASB, 2006g). More particularly, the project refers to measuring fair values based on

(1) quoted prices for identical items on an active market;

(2) quoted prices of similar items on an active market, if (1) is not possible; or

(3) valuation models incorporating significant entity-specific inputs, if (1) and (2) are not possible.

Given that an active market satisfying IAS 36.6 can be difficult to find for specific performance obligations, strictly applying the hierarchy means measuring fair values on level (3) in many cases (Bromwich, 2004). This will particularly apply to most obligations attributable to construction contracts. Applying the hierarchy less strictly can incorporate hypothetical prices charged by other vendors and gives rise to problems in determining the relevant market or relevant vendor.

As a major feature of the FVA, revenue (or expense) has to be recognised at the inception date if the consideration amount does not equal the aggregate of fair values of the performance obligations arising from an enforceable contract at contract inception (IASB, 2003b; Wüstemann and Kierzek, 2005).[4] Apart from subsequent remeasurement, the extinguishment of performance obligations will determine subsequent revenue recognition. The boards proposed, but did not decide on 
remeasuring contractual assets and, more importantly, contractual liabilities at their fair value (IASB, 2003a, 2005d, 2006c).

[PLEASE INSERT EXAPLE C.]

\subsection{Allocated customer consideration approach (ACCA)}

While the IASB tends to favour the FVA, the FASB rather abandoned it when reviewing the project strategy in mid-2005. The boards agreed on exploring an alternative approach measuring performance obligations based on the customer consideration amount. This is the amount of consideration paid or to be paid by the customer in a business-to-customer market. More particularly, this alternative approach aims at measuring performance obligations at the allocated customer consideration amount. This amount is determined two-fold. It is the aggregate of the (1) estimated sales price of good, service, or other right, and (2) the pro rata portion of the residual between the customer consideration amount and the sum of estimated sales prices of the performance obligations based on the relative sales price of that performance obligation (IASB 2005c; IASB and FASB, 2007).

The first component shall reflect an estimated average sales price. This is the price at which a good, service, or other right is sold or is capable of being sold on a stand-alone basis or as an optional extra. It shall be measured according to the following hierarchy based on (IASB, 2005b, 2005e, 2005f, 2007d)

(1) current sales prices charged by the reporting entity in an active market; 
(2) current sales prices charged by other vendors, e.g., competitors, in an active market, if (1) is not possible;

(3) current sales prices charged by the reporting entity in an inactive market, if (1) and (2) are not possible; or

(4) estimates reflecting entity-specific inputs, e.g., the reporting entity's estimated (average) costs plus a normal (average) profit margin, if (1) to (3) are not possible.

Much like using valuation models to construct fair values, estimated sales prices of performance obligations attributable to construction contracts will often be measured on level (4) (IASB, 2004d, 2005c). If there is a difference between the total customer consideration and the aggregate of estimated sales prices of performance obligations considered, the (positive or negative) residual shall be allocated to the performance obligations pro rata based on their estimated sales prices. This yields a measurement according to the allocated customer consideration amount, ensuring that no revenue (or expense) is recognised at contract inception in general (see Example D). Currently, the boards discuss remeasurement of performance obligations under the ACCA (IASB, 2005d, 2006c).

\section{[PLEASE INSERT EXAPLE D.]}

\subsection{Mixed approach (MA)}

While the FASB favours to measure all performance obligations at their allocated customer consideration amount, the IASB prefers to exclude (1) unconditional standready obligations and (2) obligations required to be measured at fair values by a given 
standard (IASB, 2005f, 2007d). These obligations shall be measured at fair value and no residual shall be allocated to them. Moreover, it is (3) proposed to allow or to require to measure performance obligations at their fair value if an active market exists (IASB, $2005 \mathrm{~b}, 2005 \mathrm{c})$. This results in a mixed approach (MA). It should be noted, that in the limiting case when all performance obligations are measured at their fair value, the MA equals the FVA. This, however, is unlikely when considering construction contracts.

\section{[PLEASE INSERT EXAPLE E.]}

\section{Discussion}

\subsection{Revenue-expense approach versus asset-liability approach}

As illustrated in the preceding sections the current and proposed approaches for revenue recognition for constructions contracts under IFRSs notably differ. This section critically analyses these differences to assess the implications of the IASB project Revenue Recognition on financial reporting. Concerning income concepts, recent IAS 11 is rather consistent with a revenue-expense approach whereas the project Revenue Recognition features an asset-liability approach.

Based on a revenue-expense approach, IAS 11 relates revenue recognition to realisation criteria. While the ZPMM requires recognising revenue when the contract is completed and risks and rewards are transferred, the SOCM relies on a softer realisation principle by assuming that revenue and profit arise throughout the whole construction process. The latter has a smoothing effect on revenue and profits (Paton and Littleton, 1955; 
Wüstemann and Kierzek, 2005; see Examples A and B). The need to recognise expected losses on a construction contract immediately as opposed to recognise at contract completion or allocating them according to the stage of completion indicates conservative accounting.

In contrast, the proposals of the project Revenue Recognition follow an asset-liability approach. The traditional realisation principle shall no longer serve as a rule to determine income. The US Securities and Exchange Commission even claims that the asset-liability approach "most appropriately anchors the standard setting process by providing the strongest conceptual mapping to the underlying economic reality" (FASB and IASB, 2005, p.8). Unlike under the SOCM, revenue is recognised when a critical event, i.e. the extinguishment of a performance obligation, takes place. While the assetliability approach can be seen as a sound conceptual base for revenue recognition, many problems are shifted to the measurement of performance obligations.

Significantly at this crucial point, the IASB and the FASB reached different tentative decisions (IASB and FASB, 2007). The IASB prefers performance obligations to be measured at a fair value, i.e. with reference to the market. However, the FASB is in favour of the ACCA, referring to estimated sales prices based on competitors prices or the entity's own costs in general.

While details of remeasurement are unsolved to date, the ACCA has a smoothing effect on the recognition of revenue and profit compared to fair value measurement. In contrast to the SOCM under IAS 11, the ACCA conceptually smoothes both, profits and losses (see Example D). Apart from onerous contracts under IAS 11 and IAS 37, only the FVA can require to recognise revenue or expense at contract inception (see Example 
C). This occurs if the initial sum of fair values of performance obligations does not equal the consideration amount that both parties agreed on. As an irritating consequence, a loss can occur at contract inception although performing the whole contract leads to a profit and vice versa. To illustrate this point, suppose that fair values are measured relative to competitors' prices charged. If the reporting entity is the cheapest vendor and agrees on a considerable amount below the competitors' price but above its own contract costs, a loss is recognised at contract inception although performing the whole contact yields a profit in total. Thus, the cheap vendor incurs losses when closing a profitable contract.

While the project does not intend to link revenue recognition to realisation or earnings criteria, conceptual, analytical and empirical evidence finds that disaggregating income components according to these criteria provides useful information (e.g. Edwards and Bell, 1961; Ohlson, 1999; Biddle and Choi, 2006). Suppose subsequent remeasurement of contract liabilities (or assets). Evidence implies to separately present amounts arising from remeasurement in the income statement. If expenses follow from remeasurement and are aggregated with costs of performance, the latter are not visible in the statement of (comprehensive) income. This suggests that realisation or earnings criteria are still important at least for presentation.

\subsection{Relevance versus reliability}

By relying on a softer realisation principle, the SOCM is likely to yield relevant but potentially unreliable information when compared to the ZPMM. Significantly, national GAAP in Austria and Germany do not allow the SOCM (Nobes, 2006). These GAAP 
largely rely on conservative accounting and a narrow interpretation of the realisation principle to determine the recognition of profit. They require a completed contract treatment, which differs from the ZPMM under IFRSs as no revenue is recognised until the contract is completed.

Consistent with conservative accounting, this clearly restricts managerial discretion in estimates and forecasts required under the SOCM. However, this conservative treatment tends to give rise to a lack of comparability, problems with true and fair view and misleading accounting performance, possibly resulting in unfavourable reactions by financial statement users or in unfavourable tax effects.

The adoption of IAS 11 challenges accounting for construction contracts in these conservative accounting regimes (Wüstemann and Kierzek, 2005). However, IAS 11 tries to balance relevance and reliability to some extent by requiring either the use of the ZPMM or the SOCM depending on the reliable estimation of the outcome of the construction contract (see Examples A and B; Barlev, 1995). Given the flexible criteria which determine whether the outcome can be estimated reliably, there is obvious need and room for managerial judgement.

Compared to the current IAS 11, the proposals of the project Revenue Recognition do not reduce the need for managerial judgement, e.g., with regard to (1) inception date of a contract and more obviously to (2) the measurement of performance obligations. This is ambivalent along the lines of earnings management, defined as intentionally influencing financial statement figures by real transactions and accounting choice to impact reactions by financial statement users (Dechow and Skinner, 2000; Beneish, 2001).[5] The manager may use judgement to reveal relevant (private) information or to 
exercise self-serving discretion potentially affecting reliability. In either case, comparability of financial information is impaired.

Although recognising assets and liabilities at contract inception can provide relevant, future-orientated information, contract inception (as objective formal reference) allows for discretion by referring to customer business practice (Wüstemann and Kierzek, 2005). As contract inception can change financial ratios, the proposals allow for shortterm window-dressing. Particularly, the FVA can give rise to revenue at the inception date and, thus, to real earnings management by contract inception (see Example C). While accounting literature has largely discussed the relevance-reliability trade off of fair value measurement (for survey Bromwich, 2004; Hague et al., 2006; Hitz, 2007), there is neither specific theoretical work nor empirical evidence on allocated customer consideration amounts. Although the IASB generally assumes fair values to be a relevant measurement base (Cairns, 2006; IASB, 2006g), empirical research provides mixed results on value relevance of fair values measured mark-to-market (e.g. Park, Park and Ro, 1999; Barth, Beaver and Landsman, 2001; Khurana and Kim, 2003; Graham, Lefanowicz and Petroni, 2003). Moreover, hypothetical liability extinguishment values may not be a relevant measurement base if performance extinguishment is legally prohibited, not intended or actually not transacted by the reporting entity. If market prices are not observable, fair values have to be estimated using valuation models incorporating managerial subjectivity. This challenges reliability particularly in the case of non-financial liabilities such as performance obligations arising from construction contracts (e.g. Ernst and Young, 2005). Concerning the allocated customer consideration amount, there are similar problems due to the flexibility of valuation models. Basing on estimated sales prices comparable to an exit (fair) value, the above results on relevance may merely be transferred if there are no or 
little residuals allocated to the performance obligations. However, allocated customer consideration amounts smooth differences between the sum of estimated sales prices and the total consideration in absence of subsequent remeasurement (see Example D).[6] This might be relevant given evidence that earnings smoothing can provide relevant information (e.g., Arya, Glover, and Sunder, 2003; Tucker and Zarowin, 2006).

If performance obligations are remeasured (at either value) two implications arise. First, remeasurement can give rise to valuation-based volatility in profit or loss apart from specific performance (Ballwieser, 2004). Secondly, remeasurement allows for judgement in each period and for changing accounting earnings management strategies weakly restricted by consistency required. Thus, remeasurement (most notably under the valuation-based approaches proposed, but to a lesser extent under the SOCM) is likely to challenge reliability and has arguable implications for relevance of the recognition of revenue and profit. This can impair both decision-usefulness and stewardship.

\subsection{Decision usefulness versus stewardship}

The previous section argued that the proposals do not tend to dominate IAS 11 in terms of relevance and reliability. Despite ambiguity of the terms, even under the current framework of the IASB, this questions decision-usefulness of the proposed concepts given that relevance and reliability are the main characteristics constituting decisionuseful financial reporting. Concerning stewardship, results will not change if stewardship is purely regarded as a sub-objective of decision-usefulness. Adopting an economic point of view, stewardship shall be considered in the light of impact the 
accounting system has on the manager's decisions, e.g. by management compensation based on accounting profits (Prakash and Rappaport, 1977; Ng, 1978). This view appears rather neglected in both, current assessments of standard-setters and literature on accounting for construction contracts.

The ZPMM does not reward a manager for economic performance during the periods of construction, but punishes him for expected losses on construction contracts. This can incite short-term-oriented managers not to engage in construction projects. The SOCM mitigates the problem as profits (measured relative to input spent or output performed) can approximate economic performance and reward a manager on that base.

However, the SOCM and the approaches proposed in the project Revenue Recognition share the issues of managerial discretion in measurement and room for accounting earnings management. Suppose a manager plans to leave the entity. He will have incentives to calculate upward-biased stages of completion for early periods or upwardbiased fair values for performance obligations first extinguished if the sum of fair values of performance obligations is kept stable (see Example C). If the sum of fair values of performance obligations may change, the need to recognise an excess of the sum of fair values over total consideration as a loss is eager to benchmark and to limit incentives to calculate upward-biased fair values.

The allocated customer consideration amount is ambivalent in this regard, too. Given an excess of total consideration over the sum of estimated sales prices, managers will calculate upward estimated sales prices for performance obligations first performed which are allocated a larger proportion of the positive residual. In the reverted case, when a negative residual has to be allocated, there are incentives to calculate either 
upward- or downward-biased estimated sales prices for performance obligations first extinguished. This depends on the amount of the residual to be allocated relative to the sales prices to be estimated (see Examples D and E).

While specific results on allocated customer consideration amounts are missing, analytical models on stewardship find cost accounting superior to fair value accounting under most circumstances (Dutta and Zhang, 2002; Baldenius and Reichelstein, 2005). Kwon (2005) even suggests conservative accounting is superior since it motivates the manager to increase effort. Consistent with room for judgement, this implies that the FVA is rather inappropriate for stewardship purposes.

Most notably under the FVA, profit or loss is anticipated relative to the sum of extinguishment values at inception date (see Example C). If a profit occurs at contract inception, the manager is rewarded for a positive result measured relative to the market, not relative to construction cost. Even apart from remeasurement, losses can be recognised in the intermediate periods, although a profit can result overall. This implies to close contracts that lead to high profits at inception if the manager plans to leave the company. Incentives to inflate revenues by contracting at dumping prices are limited, however, because any excess of the sum of fair values over the consideration amount shall be recognised as expense in the period of contract inception. If a loss results at contract inception with profits recognised later on, the manager is punished for contract inception although an overall profitable contract is placed. This can create incentives not to close economically beneficial contracts (Jensen and Smith, 1985). As a consequence, over- or underinvestment problems can occur. 


\subsection{Current versus future regulatory compatibility}

The last two sections particularly identified that the approaches proposed in the project Revenue Recognition, particularly the FVA, seriously conflict with reliability and with stewardship required by the current framework of the IASB (and the FASB). While the accounting purposes and terms are ambiguous (Will, 2006), this section addresses various incompatibilities in the light of current (supra)national regulatory frameworks and potential future regulation based on new developments at the IASB.

Depending on domestic or supranational institutional settings, IFRSs (as standards of a private standard-setter) have to meet certain criteria to be adopted or transformed into law. For instance, the endorsement criteria set out in Art. 3(2) of Regulation (EC) $1606 / 2002$ require standards to satisfy reliable information to assess stewardship of management. These criteria might be a more profound obstacle for the endorsement of a standard following the proposals in the European Union than the true and fair view controversially discussed in recent papers (Wüstemann and Kierzek, 2005, 2006; Alexander, 2006; Nobes, 2006). The European Union can exert pressure on the IASB not only ex-post by not endorsing a standard, but also ex-ante by threatening to do so. Thus, it is likely that at least a pure FVA will be overruled. This tends to be supported by the FASB preferring the ACCA.

The proposed future objectives and characteristics of financial reporting discussed in the joint IASB/FASB project Conceptual Framework appear to reduce the risk incompatibilities of the new approaches with the framework (IASB, 2006f, 2007a). First, the proposals replace reliability by faithful representation. While both terms are ambiguous, the IASB assumes faithful representation to be less critical but comprising 
all characteristics of reliability. Emerging on a terminological level at first sight, the proposed change might urge a more permissive interpretation of the characteristic compared to reliability. Secondly, the proposals subsume stewardship under decisionusefulness, i.e. stewardship shall be no self-contained objective of financial reporting. This is surprising in the view of the double-semiotic meaning of stewardship (Will, 2006) and neglects to consider the effects of incentives for real and accounting earnings management set by financial reporting standards, reaffirming a lesser weight on reliability of financial reporting.

Concerning recognition, the definitions of assets and liabilities in the current Framework 49 include an undefined probability criterion not explicitly required for contractual assets and liabilities in the project Revenue Recognition. Again this conflict might be mitigated as the boards plan to abandon the probability criterion in revising the definitions in the project Conceptual Framework (IASB, 2007a).

While this suggests that current inconsistencies in IFRSs can be overcome by a major revision of concepts in interacting projects, there are developments at the IASB that may lead to new inconsistencies. To illustrate this point, it is sufficient to revert to two projects, i.e. Liabilities (IASB, 2005g) and Insurance Contracts (phase II) (IASB, 2007c), both featuring an asset-liability approach. The proposals on amending IAS 37 imply measuring non-financial liabilities "at the amount that it would rationally pay to settle the present obligation or to transfer it to a third party on the balance sheet date" using "an expected cash flow approach" in general (IASB, 2005g, p.28). Implicitly, the board appears to refer to some kind of ambiguous ,fair value“. 
Insurance liabilities are about to be measured at a current exit value (IASB, 2007c). Here, the IASB states: "It is too early to conclude whether current exit value is synonymous with fair value. The Board will review that question as work proceeds on the Board's fair value measurement project" (IASB, 2006h, para. 26). Assuming the measures are fair values (IASB, 2006g), both projects conflict with the ACCA, but might fit with the MA or the FVA. Even assuming fair value measurement, there is still controversity on whether or not to allow for profit or loss at the inception date of an insurance contract. To avoid profit or loss at contract inception, the project Insurance Contracts suggests to adjust risk margins or to include service margins in measuring insurance liabilities. Yet, this is implies inconsistencies with the FVA as proposed in the project Revenue Recognition.

Such inconsistencies are attributable to the ambiguity of terms, most notably of fair value as well as to (partly) missing links among current projects. Yet, a close collaboration among current projects is essential as they lack an appropriate framework as a coherent and cohesive base for developing consistent standards to date. The proceeding of major projects, like Revenue Recognition, will drive the development of a future framework for financial reporting, rather than vice versa.

\section{Conclusions}

This paper has illustrated and evaluated the impact of the proposals of the IASB/FASBproject Revenue Recognition on financial reporting for construction contracts under IFRSs. Featuring an asset-liability approach as opposed to a revenue-expense approach and measurement at fair values or allocated customer consideration amounts, the 
proposals have far-reaching consequences on revenue and profit recognition when compared to IAS 11. The Appendix A summarises the differences between the approaches and their consequences. Semantic and pragmatic problems with reliability and stewardship cause inconsistencies with both the current framework of the IASB and endorsement criteria set out by the European Union (Regulation (EC) 1606/2002, Art. 3(2)). While the former can be mitigated by revising the framework as currently proposed, the latter tend to remain and are likely to impede the adoption of the FVA for construction contracts under IFRSs. In conclusion, the ACCA or the MA proposed are more likely to be followed.

The paper is among the very first to discuss the proposals of the project Revenue Recognition critically and has questioned various concepts applied with particular reference to construction contracts. Further details of aggregation or segmentation of contracts, multi-element arrangements or on the separation of revenue components are still under discussion. The IASB and the FASB plan to publish a discussion paper in mid-2008, presenting both the FVA and the ACCA as well as proposals for the MA (IASB, 2006e, 2007b; IASB and FASB, 2007). The project is an opportunity to establish a coherent and consistent conceptual foundation for revenue recognition and income determination under IFRSs and deserves further deliberation and discussion among academics, professionals and regulatory bodies. 


\section{Acknowledgements}

The author wants to thank the editor Jason C.H. Chen, three anonymous reviewers, Silvia Hettich, participants of the 29th Annual Conference of the European Accounting Association in Dublin and seminar participants at the Ludwig-Maximilians-University of Munich for their constructive criticism and suggestions for improvements 


\section{References}

Alexander, D. (2006) 'Legal certainty, European-ness and realpolitik', Accounting in Europe, Vol. 3, pp.65-80.

Antle, R. and Demski, J.S. (1989) 'Revenue recognition', Contemporary Accounting Research, Vol. 5, pp.423-451.

Arya, A., Glover, J.C. and Sunder, S. (2003) 'Are unmanaged earnings always better for shareholders?', Accounting Horizons, Vol. 17, pp.111-116.

Baldenius, T. and Reichelstein, S. (2005) 'Incentives for efficient inventory management: the role of historical cost', Management Science, Vol. 51, pp.10321045.

Ballwieser, W. (2004) 'The limitations of financial reporting', in C. Leuz, D. Pfaff and A. Hopwood (Eds), The Economics and Politics of Accounting (pp.58-77). Oxford: Oxford University Press.

Barlev, B. (1995) 'Determining the stage at which it is appropriate to recognise profit under long-term construction' Journal of Business Finance and Accounting, Vol. 22, pp.713-731.

Barth, M.E., Beaver, W.H. and Landsman, W.R. (2001) 'The relevance of the value relevance literature for financial accounting standard setting: another view', Journal of Accounting and Economics, Vol. 31, pp.77-104.

Beaver, W.H. and Demski, J.S. (1979) 'The nature of income measurement', The Accounting Review, Vol. 54, pp.38-46.

Belkaoui, A.R. (2000) Accounting Theory (4th ed.). London: University Press Cambridge.

Beneish, M.D. (2001) 'Earnings management: a perspective', Managerial Finance, Vol. 27, pp.3-17.

Benston, G., Bromwich, M., Litan, R.E. and Wagenhofer, A. (2003) Following the Money: the Enron Failure and the State of Corporate Disclosure. Washington: AEI-Brookings Center for Regulatory Studies.

Benston, G., Bromwich, M., Litan, R.E. and Wagenhofer, A. (2006) Worldwide Financial Reporting. Oxford: Oxford University Press.

Berle, A.A. and Means, G.C. (1932) The Modern Corporation and Private Property. New York Harcourt, Brace \& World.

Biddle, G.C. and Choi, J-H. (2006) 'Is comprehensive income useful?', Journal of Contemporary Accounting and Economics, Vol. 2, pp.1-32.

Birnberg, J.G. (1980) 'The role of accounting in financial disclosure', Accounting, Organization and Society, Vol. 5, pp.71-80.

Bromwich, M. (2004) 'Aspects of the future in accounting: the use of market prices and 'fair values' in financial reports', in C. Leuz, D. Pfaff and A. Hopwood (Eds), The Economics and Politics of Accounting (pp.32-57). Oxford: Oxford University Press.

Cairns, D. (2006) 'The use of fair value in IFRS', Accounting in Europe, Vol. 3, pp.522.

Chambers, R.J. (1966) Accounting, Evaluation and Economic Behaviour. Englewood Cliffs: Prentice Hall.

Chase, C.W. Jr., (1999) 'Revenue management: a review', Journal of Business Forecasting Methods and Systems, Vol. 18, pp.2, 28-30.

Chiang, W.-C., Chen, J.C.H. and Xi, X. (2007) 'An overview of research on revenue management: current issues and future research', Int. J. Revenue Management, Vol. 1, pp.97-128. 
Christensen, J.A. and Demski, J.S. (2003) Accounting Theory - an Information Content Perspective. Boston: McGraw-Hill.

Crawford, V. and Sobel, J. (1982) 'Strategic information transmission', Econometrica, Vol. 50, pp.1431-1451.

Dechow, P. and Skinner, D.J. (2000) 'Earnings management: reconciling the views of accounting academics, practitioners and regulators', Accounting Horizons, Vol. 14, pp.235-250.

Demski, J.S. (1973) 'The general impossibility of normative accounting standards', The Accounting Review, Vol. 48, pp.718-723.

Demski, J.S. (1980) Accounting Theory (2nd ed.). Reading: Addison-Wesley.

Devine, C.T. (1963) 'The role of conservatism re-examined', Journal of Accounting Research, Vol. 1, pp.127-138.

Dutta, S. and Zhang, X.-J. (2002) 'Revenue recognition in a multiperiod agency setting', Journal of Accounting Research, Vol. 40, pp.67-83.

Edwards, E.O. and Bell, P.W. (1961) The Theory and Measurement of Business Income. Berkeley: University of California Press.

Ernst and Young (2005) How Fair is Fair Value?. London: Ernst and Young.

Ernstberger, J. (2005) 'Revenue recognition - a conceptual review of the proposed model of the IASB', Paper presented at the Proceedings of the Workshop Accounting in Europe 2005 and Beyond in Regensburg, September.

Fetzer, J.H. and Almeder, R.F. (1993) Glossary of Epistemology/Philosophy of Science. New York: Paragon House.

Fisher, I. (1906) The Nature of Capital and Income. New York, NY: Macmillan.

Gjesdal, F. (1981) 'Accounting for stewardship', Journal of Accounting Research, Vol. 19, pp.208-231.

Government Accountability Office (2002) Financial Statement Restatements - Trends, Market Impacts, Regulatory Responses, and Remaining Challenges. Report GAO03-138, Washington (www.gao.gov).

Government Accountability Office (2006) Financial Restatements - Update of Public Company Trends, Market Impacts, and Regulatory Enforcement Activities. Report GAO-06-678, Washington (www.gao.gov).

Graham, R.C., Lefanowicz, C.E. and Petroni, K.R. (2003) 'The value relevance of equity method fair value disclosures', Journal of Business Finance and Accounting, Vol. 30, pp.1065-1088.

Hague, I.P.N., Jones, K., Milburn, A. and Walsh, M. (2006) 'New developments in the framework for financial reporting: the role of national standard setters and the Canadian contribution to research on measurement on initial recognition and a framework for disclosure of financial information', Journal of International Financial Management and Accounting, Vol. 17, pp.256-270.

Haller, A. and Schloßgangl, M. (2005) 'Shortcomings of performance reporting under IAS/IFRS: a conceptual and empirical study', Int. J. Accounting, Auditing and Performance Evaluation, Vol. 2, pp.281-299.

Harris, F.H.deB. (2007) 'Large-scale entry deterrence of a low-cost competitor: an early success of airline revenue management', Int. J. Revenue Management, Vol. 1, pp.5-27.

Hitz, M. (2007) 'The decision-usefulness of fair value accounting - a theoretical perspective', The European Accounting Review, Vol. 16, pp.323-362.

Hunt, S.C. (1995) 'A review and synthesis of research in performance evaluation in public accounting', Journal of Accounting Literature, Vol. 15, pp.107-139.

Ijiri, Y.C. (1975) Theory of Accounting Measurement. Sarasota American Accounting Association. 
Jensen, M.C. and Smith, C.W. Jr. (1985) 'Stockholder, manager, and creditor interests: applications of agency theory', in E.I. Altman and M.G. Subrahmanyam (Eds), Recent Advances in Corporate Finance (pp.93-131). Homewood: Irwin.

Khurana, I.K. and Kim, M.-S. (2003) 'Relative value relevance of historical cost vs. fair value: evidence from bank holding companies', Journal of Accounting and Public Policy, Vol. 22, pp.19-42.

Kosiol, E. (1978) Pagatoric Theory of Financial Income Determination. Urbana: Center for Education and Research in Accounting.

Kothari, S.P. (2001) 'Capital markets research in accounting', Journal of Accounting and Economics, Vol. 31, pp.105-231.

Kwon, Y.K. (2005) 'Accounting conservatism and managerial incentives', Management Science, Vol. 51, pp.1626-1632.

Leuz, C. (1998) 'The role of accrual accounting in restricting dividends to shareholders', The European Accounting Review, Vol. 7, pp.597-604.

$\mathrm{Ng}$, D.S. (1978) 'An information economics analysis of financial reporting and external auditing', The Accounting Review, Vol. 53, pp.910-920.

Nobes, C.W. (2006) 'Revenue recognition and EU endorsement of IFRSs', Accounting in Europe, Vol. 3, pp.81-89.

Ohlson, J.A. (1999) 'On transitory earnings', Review of Accounting Studies, Vol. 4, pp.145-162.

Park, M., Park, T. and Ro, B.T. (1999) 'Fair value disclosures for investment securities and bank equity: evidence from SFAS 115', Journal of Accounting, Auditing and Finance, Vol. 14, pp.347-370.

Paton, W.A. and Littleton, A.C. (1955) An Introduction to Corporate Accounting Standards (6th print). Ann Arbor: American Accounting Association.

Prakash, P. and Rappaport, A. (1977) 'Information inductance and its significance for accounting', Accounting, Organizations and Society, Vol. 2, pp.29-38.

Smith, A. (1870) An Enquiry into the Nature and Causes of the Wealth of Nations (reprint of the 1812 ed.). London: Ward, Lock.

Solomons, D. (1961) 'Economic and accounting concepts of income', The Accounting Review, Vol. 36, pp.374-383.

Trotman, K.T. and Zimmer, I.R. (1986) 'Revenue recognition in the construction industry: an experimental study', Abacus, Vol. 22, pp.136-147.

Tucker, J. and Zarowin, P. (2006) 'Does income smoothing improve earnings informativeness?', The Accounting Review, Vol. 81, pp.251-270.

Will, H. (2006) 'Knowledge management and administration depend on semiotic information systems', Int. J. Management and Decision Making, Vol. 7, pp.36-57.

Wüstemann, J. and Kierzek, S. (2005) 'Revenue recognition under IFRS revisited: conceptual models, current proposals and practical consequences', Accounting in Europe, Vol. 2, pp.69-106.

Wüstemann, J. and Kierzek, S. (2006) 'True and fair view revisited - a reply to Alexander and Nobes', Accounting in Europe, Vol. 3, pp.91-116. 


\section{Regulatory materials}

FASB (2002) Minutes: Revenue Recognition. Joint FASB/IASB Board Meeting 25.9.2002.

FASB (2005) Selected Issues Relating to Assets and Liabilities with Uncertainties. Financial Accounting Series 1235-001, September.

FASB and IASB (2005) Revisiting the Concepts: A New Conceptual Framework Project, May.

IASB (2002) IASB Update, September.

IASB (2003a) IASB Update, July.

IASB (2003b) Information for Observers: Revenue Recognition. Board Meeting, 17.19.9.2003.

IASB (2004a) IASB Update, January.

IASB (2004b) IASB Insight, October/November.

IASB (2004c) Information for Observers: Revenue Recognition. Board Meeting, 17.19.3.2005.

IASB (2004d) Information for Observers: Revenue Recognition. Board Meeting, 22.6.2004.

IASB (2005a) IASB Update, June.

IASB (2005b) IASB Update, September.

IASB (2005c) IASB Update, October.

IASB (2005d) Information for Observers: Revenue Recognition. Board Meeting, 22.23.6.2005.

IASB (2005e) Information for Observers: Revenue Recognition. Board Meeting, 20.9.2005.

IASB (2005f) Information for Observers: Revenue Recognition. Board Meeting, 19.10.2005.

IASB (2005g) Exposure Draft: Proposed Amendments to IAS 37 Provisions, Contingent Liabilities and Contingent Assets and IAS 19 Employee Benefits, June.

IASB (2006a) IASB Update, January.

IASB (2006b) IASB Update, July.

IASB (2006c) IASB Update, September.

IASB (2006d) Information for Observers: Revenue Recognition. Board Meeting, 20.7.2006.

IASB (2006e) Information for Observers: Revenue Recognition. Board Meeting, 19.9.2006.

IASB (2006f) Discussion Paper: Preliminary Views on an Improved Conceptual

Framework for Financial Reporting: The Objectives of Financial Reporting and

Qualitative Characteristics of Decision-useful Financial Reporting Information, July.

IASB (2006g) Discussion Paper: Fair Value Measurements, November.

IASB (2006h) Project Update: Insurance Contracts (Phase II), December.

IASB (2007a) Project Update: Conceptual Framework, July.

IASB (2007b) IASB Update, October.

IASB (2007c) Discussion Paper: Preliminary Views on Insurance Contracts, May.

IASB and FASB (2007) Information for Observers: Revenue Recognition. IASB/FASB

Meeting, 22.10.2007.

All regulatory materials are available at the websites of the FASB (www.fasb.org) or the IASB (www.iasb.org), respectively. 


\section{Standards/Framework}

IAS 8 (2003) Accounting Policies, Changes in Accounting Estimates and Errors.

IAS 11 (1993) Construction Contracts.

IAS 18 (1993) Revenue.

IAS 36 (2003) Impairment of Assets.

IAS 37 (1998) Provisions, Contingent Liabilities and Contingent Assets.

IAS 39 (2005) Financial Instruments: Recognition and Measurement.

IAS 41 (2000) Agriculture.

IASB Framework (1989) Framework for the Preparation and Presentation of Financial Instruments.

SOP 81-1 (1981) Accounting for Performance of Construction-Type and Certain Production-Type Contracts. 


\section{Notes}

[1] Particularly, since financial reporting addresses multiple and inhomogeneous users, the economics of information perspective can not legitimate (normative) standardsetting (Demski, 1973). Empirical accounting research tends to rely on statistical relevance, e.g., based on the concept of value relevance.

[2] IAS 11.22 requires that both contract revenues and contract costs to be recognised as revenue and expense respectively according to the stage of completion. This prohibits an adjustment of contract revenue, e.g., as allowed under US GAAP (SOP 81-1). Adjusting contract costs requires (1) positive accruals when contract costs incurred in a period exceed expenses according to the stage of completion of the period and (2) negative accruals in the reverse case.

[3] This corresponds with distinguishing contractual obligations settled by financial or non-financial items in the course financial instruments (IAS 39.5).

[4] Yet, under current IFRSs, initial recognition of financial instruments or biological assets at fair value can give rise to profit or loss (IAS 39, IAS 41).

[5] Taking a pure financial reporting perspective, revenue management might be defined analogously to earnings management, focussing on revenue as the top line of income statements.

[6] Considering a construction contract, any multiplicative transformation of the vector of estimated sales prices (with the multiplier differing from zero) yields an equal vector of allocated customer consideration amounts of the performance obligations. 


\section{Example A: ZPMM}

Suppose a reporting entity which incepts an enforceable contract in $t_{0}$ with total customer consideration of 120 . From $t_{1}$ to $t_{4}$ the entity performs a separate performance obligation in each period. Contract costs are 40 in $t_{1}, 20$ in $t_{2}, 25$ in $t_{3}$ and 15 in $t_{4}$, yielding total contract costs of 100 . In $t_{4}$ the customer accepts the work and is charged 120. For simplicity, all examples do not consider (1) problems of disaggregating performance obligations, (2) remeasurement of performance assets and liabilities, and (3) deferred taxes.

To illustrate the ZPMM suppose that the outcome of the construction contract cannot be estimated reliably during $\mathrm{t}_{1}$ to $\mathrm{t}_{3}$.

\begin{tabular}{|l|c|c|c|c|c|c|}
\cline { 2 - 7 } \multicolumn{1}{c|}{} & $\mathbf{t}_{\mathbf{0}}$ & $\mathbf{t}_{\mathbf{1}}$ & $\mathbf{t}_{\mathbf{2}}$ & $\mathbf{t}_{\mathbf{3}}$ & $\mathbf{t}_{\mathbf{4}}$ & sum \\
\hline revenue & - & 40 & 20 & 25 & 35 & 120 \\
\hline expense & - & 40 & 20 & 25 & 15 & 100 \\
\hline gross profit & - & $\mathbf{0}$ & $\mathbf{0}$ & $\mathbf{0}$ & $\mathbf{2 0}$ & $\mathbf{2 0}$ \\
\hline contract asset & - & 40 & 60 & 85 & 120 & \multicolumn{2}{c}{} \\
\hline contract liabilities & - & - & - & - & - \\
\cline { 1 - 6 }
\end{tabular}


Example B: SOCM

Suppose the outcome of the construction contract can be estimated reliably and the stage of completion is determined by reference to contract costs incurred for work performed.

\begin{tabular}{|l|c|c|c|c|c|c|}
\cline { 2 - 7 } \multicolumn{1}{c|}{} & $\mathbf{t}_{\mathbf{0}}$ & $\mathbf{t}_{\mathbf{1}}$ & $\mathbf{t}_{\mathbf{2}}$ & $\mathbf{t}_{\mathbf{3}}$ & $\mathbf{t}_{\mathbf{4}}$ & sum \\
\hline revenue & - & 48 & 24 & 30 & 18 & 120 \\
\hline expense & - & 40 & 20 & 25 & 15 & 100 \\
\hline gross profit & - & $\mathbf{8}$ & $\mathbf{4}$ & $\mathbf{5}$ & $\mathbf{3}$ & $\mathbf{2 0}$ \\
\hline contract asset & - & 48 & 72 & 102 & 120 & \\
\hline contract liabilities & - & - & - & - & - \\
\hline
\end{tabular}




\section{Example C: FVA}

C1. Suppose an enforceable (e.g., prepaid) construction contract where the fair values of each performance obligation from $t_{1}$ to $t_{4}$ is 35 , i.e., 140 in total. This exceeds total customer consideration by 20 .

\begin{tabular}{|l|c|c|c|c|c|c|}
\cline { 2 - 7 } \multicolumn{1}{c|}{} & $\mathbf{t}_{\mathbf{0}}$ & $\mathbf{t}_{\mathbf{1}}$ & $\mathbf{t}_{\mathbf{2}}$ & $\mathbf{t}_{\mathbf{3}}$ & $\mathbf{t}_{\mathbf{4}}$ & sum \\
\hline revenue & $(20)$ & 35 & 35 & 35 & 35 & 120 \\
\hline expense & $=$ & 40 & 20 & 25 & 15 & 100 \\
\hline gross profit & $\mathbf{( 2 0 )}$ & $\mathbf{( 5 )}$ & $\mathbf{1 5}$ & $\mathbf{1 0}$ & $\mathbf{2 0}$ & $\mathbf{2 0}$ \\
\hline contract asset & 120 & 120 & 120 & 120 & 120 & \multicolumn{1}{c}{} \\
\cline { 1 - 7 } contract liabilities & 140 & 105 & 70 & 35 & - & \multicolumn{2}{c}{} \\
\cline { 1 - 7 } & & &
\end{tabular}

C2. Suppose the fair value of the each performance obligation is 25 instead of 35 . Their sum falls below total customer consideration by 20 .

\begin{tabular}{|l|c|c|c|c|c|c|}
\cline { 2 - 7 } \multicolumn{1}{c|}{} & $\mathbf{t}_{\mathbf{0}}$ & $\mathbf{t}_{\mathbf{1}}$ & $\mathbf{t}_{\mathbf{2}}$ & $\mathbf{t}_{\mathbf{3}}$ & $\mathbf{t}_{\mathbf{4}}$ & sum \\
\hline revenue & 20 & 25 & 25 & 25 & 25 & 120 \\
\hline expense & - & 40 & 20 & 25 & 15 & 100 \\
\hline gross profit & $\mathbf{2 0}$ & $\mathbf{( 1 5 )}$ & $\mathbf{5}$ & $\mathbf{0}$ & $\mathbf{1 0}$ & $\mathbf{2 0}$ \\
\hline contract asset & 120 & 120 & 120 & 120 & 120 & \multicolumn{1}{c}{} \\
\cline { 1 - 6 } contract liabilities & 100 & 75 & 50 & 25 & - & \multicolumn{2}{c}{} \\
\cline { 1 - 7 } & & & &
\end{tabular}




\section{Example D: ACCA}

D1. Suppose the estimated sales price of each performance obligation is 35 , i.e., yielding a total of 140 . The negative residual of (20) to total customer consideration is allocated pro rata to the four performance obligations from $t_{1}$ to $t_{4}$, each measured at 30 .

\begin{tabular}{|l|c|c|c|c|c|c|}
\cline { 2 - 7 } \multicolumn{1}{c|}{} & $\mathbf{t}_{\mathbf{0}}$ & $\mathbf{t}_{\mathbf{1}}$ & $\mathbf{t}_{\mathbf{2}}$ & $\mathbf{t}_{\mathbf{3}}$ & $\mathbf{t}_{\mathbf{4}}$ & Sum \\
\hline revenue & - & 30 & 30 & 30 & 30 & 120 \\
\hline expense & - & 40 & 20 & 25 & 15 & 100 \\
\hline gross profit & - & $\mathbf{( 1 0 )}$ & $\mathbf{1 0}$ & $\mathbf{5}$ & $\mathbf{1 5}$ & $\mathbf{2 0}$ \\
\hline contract asset & 120 & 120 & 120 & 120 & 120 & \multicolumn{2}{c}{} \\
\hline contract liabilities & 120 & 90 & 60 & 30 & -
\end{tabular}

D2. Suppose the estimated sales price underlying each performance obligation is 25 instead of 35 .

Allocating the positive residual of 20 yields the same result as in example D1. 


\section{Example E: MA}

Suppose that estimated sales prices of the performance obligations in $t_{1}$ and $t_{2}$ are 25 each, while fair values of the performance obligations in $t_{3}$ and $t_{4}$ are 25 each. The residual of 20 is only allocated to the obligations performed in $t_{1}$ and $t_{2}$ which are measured at 35 each.

\begin{tabular}{|l|c|c|c|c|c|c|}
\cline { 2 - 7 } \multicolumn{1}{c|}{} & $\mathbf{t}_{\mathbf{0}}$ & $\mathbf{t}_{\mathbf{1}}$ & $\mathbf{t}_{\mathbf{2}}$ & $\mathbf{t}_{\mathbf{3}}$ & $\mathbf{t}_{\mathbf{4}}$ & sum \\
\hline revenue & - & 35 & 35 & 25 & 25 & 120 \\
\hline expense & - & 40 & 20 & 25 & 15 & 100 \\
\hline gross profit & - & $\mathbf{( 5 )}$ & $\mathbf{1 5}$ & $\mathbf{0}$ & $\mathbf{1 0}$ & $\mathbf{2 0}$ \\
\hline contract asset & 120 & 120 & 120 & 120 & 120 & \\
\hline contract liabilities & 120 & 85 & 50 & 25 & - \\
\hline
\end{tabular}




\section{Appendix}

\begin{tabular}{|c|c|c|c|c|c|}
\hline & $\begin{array}{c}\text { zero profit margin method } \\
\text { (ZPMM) }\end{array}$ & $\begin{array}{c}\text { stage of completion method } \\
\text { (SOCM) }\end{array}$ & $\begin{array}{c}\text { fair value approach } \\
\text { (FVA) }\end{array}$ & $\begin{array}{c}\text { allocated customer } \\
\text { consideration approach } \\
\text { (ACCA) }\end{array}$ & $\begin{array}{c}\text { mixed approach } \\
\text { (MA) }\end{array}$ \\
\hline $\begin{array}{l}\text { regulation according } \\
\text { to IFRSs }\end{array}$ & IAS 11.32 & IAS 11.22 & $\begin{array}{l}\text { project proposal rather } \\
\text { favoured by the IASB }\end{array}$ & $\begin{array}{l}\text { project proposal rather } \\
\text { favoured by the FASB }\end{array}$ & compromise project proposal \\
\hline example & A & $\mathrm{B}$ & $\mathrm{C}$ & $\mathrm{D}$ & $\mathrm{E}$ \\
\hline concept & revenue-expense approach & revenue-expense approach & asset-liability approach & asset-liability approach & asset-liability approach \\
\hline $\begin{array}{l}\text { benchmark for } \\
\text { revenue recognition }\end{array}$ & recoverable contract cost & stage of completion & market prices & estimated sales prices & $\begin{array}{l}\text { market prices or estimated } \\
\text { sales prices }\end{array}$ \\
\hline $\begin{array}{l}\text { benchmark for profit } \\
\text { recognition }\end{array}$ & contract completion & stage of completion & $\begin{array}{l}\text { extinguishment/performance } \\
\text { of performance obligations }\end{array}$ & $\begin{array}{l}\text { extinguishment/performance } \\
\text { of performance obligations }\end{array}$ & $\begin{array}{l}\text { extinguishment/performance } \\
\text { of performance obligations }\end{array}$ \\
\hline $\begin{array}{l}\text { benchmark for loss } \\
\text { recognition }\end{array}$ & $\begin{array}{l}\text { probable loss on } \\
\text { construction contract }\end{array}$ & $\begin{array}{l}\text { probable loss on } \\
\text { construction contract }\end{array}$ & $\begin{array}{l}\text { measurement of } \\
\text { performance obligations, } \\
\text { probably remeasurement }\end{array}$ & $\begin{array}{l}\text { measurement of } \\
\text { performance obligations, } \\
\text { potentially remeasurement }\end{array}$ & $\begin{array}{l}\text { measurement of } \\
\text { performance obligations, } \\
\text { potentially remeasurement }\end{array}$ \\
\hline $\begin{array}{l}\text { revenue recognition } \\
\text { at contract inception }\end{array}$ & $\begin{array}{l}\text { no, only when expected } \\
\text { overall losses }\end{array}$ & $\begin{array}{l}\text { no, only when expected } \\
\text { overall losses }\end{array}$ & $\begin{array}{l}\text { yes, if fair values of } \\
\text { performance obligations } \\
\text { differ from consideration } \\
\text { amount }\end{array}$ & no & $\begin{array}{l}\text { no in general, but possible } \\
\text { depending on measurement } \\
\text { of performance obligations }\end{array}$ \\
\hline remeasurement & - & yes & unsolved, but probable & unsolved & unsolved, partly probable \\
\hline $\begin{array}{l}\text { conservative } \\
\text { accounting }\end{array}$ & yes, strong & $\begin{array}{l}\text { yes, due to immediate loss } \\
\text { recognition }\end{array}$ & no & $\begin{array}{l}\text { no, apart from } \\
\text { remeasurement }\end{array}$ & $\begin{array}{l}\text { no, partly depending on } \\
\text { remeasurement }\end{array}$ \\
\hline relevance & Low & rather high & disputable & disputable & disputable \\
\hline reliability & High & rather low & low & low & low \\
\hline decision usefulness & rather low & disputable & rather low, but disputable & disputable & disputable \\
\hline stewardship & low, but reliable & $\begin{array}{l}\text { rather high, but managerial } \\
\text { discretion }\end{array}$ & low & $\begin{array}{l}\text { rather high, but managerial } \\
\text { discretion }\end{array}$ & $\begin{array}{l}\text { disputable, depending on } \\
\text { measurement, but } \\
\text { managerial discretion }\end{array}$ \\
\hline
\end{tabular}

Synopsis of differences in approaches for revenue recognition for construction contracts under IFRSs. 